\title{
Corrosion Behavior of Au Coating on 316L Bipolar Plate in Accelerated PEMFC Environment
}

\author{
Chen Wen ${ }^{1,2}$, Junwei An ${ }^{1,3, *}$, Jimin Hua ${ }^{3}$, Xiaoting Lv $^{3}$, Liangxi Ding ${ }^{1}$, Xiaolin Qiu ${ }^{1}$, \\ ${ }^{1}$ Nanchang Institute of Technology, Nanchang, Jiangxi, 311033, China; \\ ${ }^{2}$ Beijing Spacecrafts, China Academy of Space Technology, Beijing, 100190, China \\ ${ }^{3}$ Inner Mongolia Qingmeng New Materials Co., Ltd., Inner Mongolia Municipality, 013560, China \\ *E-mail: 15810532852@126.com
}

Received: 17 May 2021 / Accepted: 12 September 2021 / Published: 10 October 2021

\begin{abstract}
The material Au has high conductivity and good corrosion resistance, which is benefit for proton exchange membrane fuel cells (PEMFC) application. In order to evaluate the corrosion performance of $\mathrm{Au}$ coating for PEMFC applications, the electrochemical corrosion behaviors in $0.5 \mathrm{M} \mathrm{H}_{2} \mathrm{SO}_{4}$ with 10 ppm of fluoride ions at $80{ }^{\circ} \mathrm{C}$ were investigated by potentiodynamic polarization (PP) tests. And the corrosion characteristics were characterized by using SEM, EDX, XRD and XPS methods. The results showed that as the experiment time increases from $0 \mathrm{~h}$ to $48 \mathrm{~h}$, the self-corrosion current increases from $1.716 \times 10^{-5} \mathrm{~A} / \mathrm{cm}^{2}$ to $2.243 \times 10^{-4} \mathrm{~A} / \mathrm{cm}^{2}$. As the reaction develops, the corrosion rate of the Au coating in accelerated PEMFC environment increases. Combined with the morphologies and corrosion products analysis, and also electrochemical impedance spectroscopy (EIS), the corrosion mechanisms were discussed.
\end{abstract}

Keywords: Au Coating, Corrosion, Electrochemical, PEMFC

\section{$\underline{\text { FULL TEXT }}$}

(C) 2021 The Authors. Published by ESG (www.electrochemsci.org). This article is an open access article distributed under the terms and conditions of the Creative Commons Attribution license (http://creativecommons.org/licenses/by/4.0/). 